University of Nebraska - Lincoln

DigitalCommons@University of Nebraska - Lincoln

French Language and Literature Papers

Modern Languages and Literatures, Department

July 1998

\title{
Future Mallarmé (Present Picasso): Portraiture and Self- portraiture in Poetry and Art
}

Marshall C. Olds

University of Nebraska-Lincoln, molds2@unl.edu

Follow this and additional works at: https://digitalcommons.unl.edu/modlangfrench

Part of the Modern Languages Commons

Olds, Marshall C., "Future Mallarmé (Present Picasso): Portraiture and Self-portraiture in Poetry and Art" (1998). French Language and Literature Papers. 45.

https://digitalcommons.unl.edu/modlangfrench/45

This Article is brought to you for free and open access by the Modern Languages and Literatures, Department of at DigitalCommons@University of Nebraska - Lincoln. It has been accepted for inclusion in French Language and Literature Papers by an authorized administrator of DigitalCommons@University of Nebraska - Lincoln. 


\title{
Future Mallarmé (Present Picasso): Portraiture and Self-Portraiture in Poetry and Art
}

\author{
Marshall C. Olds
}

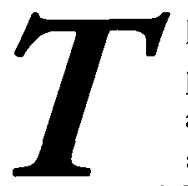

he centenary of Stéphane Mallarmés death (1898-1998) not only provides the occasion for this article and for many other publications and colloquia, but is also an appropriate moment to reflect on the afterlife of a poet who was haunted by a spectral conception of the future and for whom the pristine survival of his work was an obsessive concern. In this, Mallarmé was like other writers in kind but not in degree. He pushed a preoccupation with the future to become one the major themes of his poetry: the future seen as a distinctly literary event, at once in the poem and yet beyond it, as though the completion of the poem, the "death" of the poet, in effect marked the furure.

Maurice Blanchot grasped the complexity of this thematic configuration earlier than many of Mallarmé's commentators, as he teased out the Hegelian and Heideggerian threads that seem to run through Mallarmé, glimpsing a Dasein of all literature, always lying just ahead of us and yet already perceptible in Mallarmés poetry. It is one of the unresolvable contradictions in Mallarmé that an oeuvre so intensely focused on the linguistic medium for expression should put that medium at the service of a higher form of expression construed variously as the future, silence, the margins, the blank spaces, the white page, all that surrounds the poem and that is not the poem. As Blanchot would have it, the legacy of this body of work is not really in Mallarmés use of language, not so much in the poems themselves, as in his attitude toward language. This tension is brought out most clearly in the case of Mallarmé's greatest disciple:

Valéry a recherché la perfection de l'art, non pour cette perfection, mais pour la maîtrise qu'elle suppose et la conscience de soi qu'elle développe, tandis que Mallar- 
mé, ni moins lucide, ni moins conscient, a toujours gardé le souci de l'art et même du livre dans lequel cette lucidité et cette conscience lui ont paru pleinement s'accomplir. ... [Ses] derniers ouvrages, si admirables et si définitifs qu'ils soient, semblent les moments perdus de jours secrets, voués à une activité plus essentielle et tout intérieure. Au contraire, Valéry, n'écrivant que pour éprouver le travail de quelqu'un qui écrit, produit une oeuvre nombreuse, variée et si accomplie qu'on ne l'imagine pas doublée d'une autre plus profonde et enfermée dans le seul silence de l'esprit. Il en résulte que les idées de Mallarmé ont trouvé dans l'oeuvre de Valéry leur réalisation la plus complète, sinon la plus représentative. Mais il en résulte aussi que l'influence de Mallarmé, en grandissant avec celle de son illustre disciple, est devenue l'influence d'une théorie et d'une méthode, et a ainsi perdu ce que le mystère et la beauté des chefs-d'oeuvre ajoutent d'efficace aux idées qu'on en prétend tirer. ${ }^{1}$

That Mallarmé does not contradict Blanchot is seen in the various tombeaux poems, for instance, where the legacy of the master poet is expressed as his translation through death into the idea of himself, figured linguistically by his name. That ideal self, that name, may be a prime example of how Mallarmé's language works, a signifier having an absent signified, but it is not a word devoid of meaning. Gautier ("Toast funèbre") ${ }^{2}$ refers to the mysterious naming function of language, and Poe ("Le Tombeau d'Edgar Poe" $[O C 70]$ ) to the hieratic calling of giving a purer meaning to everyday words. These names, and here we are sent back to Blanchot, are words that evoke an attitude toward poetic language more than they do specific poems, and do indeed point to "une activité plus essentielle et tout intérieure." This last observation should come as no surprise given that Mallarmé's tombeaux are more essentially forward-looking auto-obituaries than references to the works of either Gautier or of Poe.

The question, though, is not really that of the texte and hors-texte debate, nor that of the (equally limited) analyses of l'homme et l'oeuvre. There is a third reference beyond these: l'idée de l'homme et de l'oeuvre, or put simply, l'idée de Mallarmé. This is the Mallarmé of literary and artistic "influence," but an influence so elusive, despite Valéry and to some extent W. B. Yeats and Wallace Stevens, that its importance to the future is less that of a substantial literary monument as one having iconic value. In some cases that value is cultural, an indicator of high cultural modernism. ${ }^{3}$ In others, one of which will furnish the primary example for this essay-Pablo Picasso-use of the iconic touchstone takes an intimate turn, where Mallarmé (in one form or another) becomes so deeply part of a personal mode of expression that he is barely distinguishable from the artist who uses him.

Let us now turn to what might at first seem the improbable encounter between Stéphane Mallarmé and Pablo Picasso. On the face of it, so much separates them: the one patiently mining a limited set of aesthetic notions, spending years perfecting some of his major works, the other incessantly exploring all possibilities of visual representation, moving through styles sometimes weekly, creating prodigiously in different media, living dozens of careers. In their separate ways, though, they both were extreme examples of creativity. Whether or not for that reason, Picasso turned toward (if not to) Mallarmé at two distinct points in his 
career: in 1912-16 toward the end of the cubist-collage years, and again 30 years later at the Liberation of Paris.

Let it be said at the outset that Picasso probably read little Mallarmé. In fact, though he seemed to know the titles of the latest literary works, he read little. The Romanian photographer Brassai,, whose Conversations avec Picasso give a fairly detailed, and sometimes intimate, portrait of the painter, mentions Picasso's impressive library, containing some rare volumes, but also the fact that over the years of their association (and Brassail spent many hours photographing the sculpture), never once did he or anyone else ever see Picasso reading a book. ${ }^{4}$ What is more, Picasso confessed to Brassai that the art for the many books he "illustrated" was chosen from among already extant work and simply inserted where the editor saw fit (208). It seems that Picasso was interested more in poets than in poetry, and writers were among his closest friends, especially those during the early years in Paris: Apollinaire, Cocteau, Picabia, Reverdy, and most significantly for us, Max Jacob. This last friendship was a long and, by Picasso's standards, intimate one, the painter even becoming Jacob's godfather upon his conversion to Catholicism in $1915 .^{5}$

Mallarmé's name was circulating among the avant-garde by the middle of the second decade of this century, due in large part to the 1914 publication of "Un coup de dés," the first since the original magazine edition of 1897 . We can surmise the importance of this event by the hope of at least one theatrical entrepreneur, in 1919 , to create a stage version of the poem. ${ }^{6}$ The publication has significance for us in that it occurred amid the extended public furor surrounding cubism, and it was not long before Mallarmé came to be seen, pour et contre, as an emblematic forerunner of the new sensibility in painting ( $M J \mathscr{L} P$ 252). This was not the Mallarmé of the "Faune" or of the Poe translations, though in a sense it might have been. The controversy that had arisen over the publication in 1876 of "L'après-midi d'un faune" would have a familiar echo in the painting salons of 1915 and 1916: that this new art broke all of the conventions of representation, and moreover that it was not French. The Mallarmé referred to in 1915 was of course the author of "Un coup de dés." A telling notion of the time, linking cubism to experimental literature, was seen in the term "literary cubism," and it was Max Jacob, author of short prose poems that seemed to exemplify the new genre, who was identified as "le Mallarmé du cubisme" (quoted in MJ\&P 134).

While Picasso may have heard something of Mallarmé from Apollinaire and others, Max Jacob was the likely principal source. He revered Mallarmé even above Baudelaire or Rimbaud, ${ }^{7}$ and expressed his satisfaction that "la jeunesse revient à ce maître" (MJ\&́P 145). Moreover, in 1917 Jacob would collect his prose poems under the Mallarmé-inspired title, Le Cornet à dés. Picasso was current on the project as Jacob moved forward to publication and was asked to participate with a cover illustration. (He would finally contribute a portrait of Jacob done earlier [MJ\&P 148]). It is inevitable that the painter should have known something of the origins of the curious title, and also highly unlikely that he read 
any of the poems behind it. So, whatever familiarity Picasso had with Mallarmé was mostly secondhand and filtered through Jacob.

As early as the winter of 1913-14, a dot motif had begun to appear in Picasso's work that was allied to the collage motif and, through the playing card, to games of chance. As in the "Joueur de Cartes," the random conjunction of materials and visual surfaces of the collage is given cohesion in part through the theme of chance and the person of the card player-artist. ${ }^{8}$ It is probable that the 1912 collage, "Un coup de thé," owes more than a passing nod to Mallarmé's title. ${ }^{9}$ A hearsay version of the poem and its central theme of the role of chance in art existed as an underground classic prior to the 1914 republication. But whether Picasso was aware of Mallarmé's poem in 1912, or whether the coincidence of title and partial headline (the full headline was Un coup de théatre) was itself a product of chance, by 1914 Picasso had tied these motifs to Max Jacob in a collage where cards and the poet's name figure prominently ("Hommage à Max Jacob” MJ\&P 110).

Mallarmés poem was reedited in July 1914. During that summer, Picasso was (back) in Avignon, and the collage, dots, and chance take on a new vocabulary term, the die, present in a series of paintings as a conspicuously cubist cube in one corner of intersecting planes. Art is the central theme of these works. The dominant metaphors of music (in the guitar and song, "Ma Jolie,") and games of chance (cards and dice in "Glass, Pipe, and Playing Card") again provide the focus in these collage-inspired oils ( $P$ 182). By 1916, Picasso was moving away from cubism and Mallarmés presence began to fade from his work, the die reverting to a dot motif having no cubic structure ("Still Life: $J O B$ "), and by 1917 , the dots fade into the background in an experiment with pointillism ("La Salchichona" [P 201, 202]).

Mallarmé would return to Picasso's life but in a very different way, at the end of World War II, in a series of astonishing portraits that are all the more remarkable in that they give evidence of Picasso's having read at least one poem by Mallarmé. Picasso often drew poets, but they were nearly always of the living variety and were personal friends: Jacob, Apollinaire, Cocteau, and later Eluard were frequently drawn. Portraits of past writers are very rare indeed: there is a wellknown Verlaine ( $P$ 387) that was drawn, incidently, inside a copy of Mallarmés autobiographical letter to Verlaine, along with a Mallarmé; and there are several Balzacs (P 411). (Picasso took pleasure in the fact that his studio on the quai des Grands-Augustins was purportedly the same space that Balzac gave Frenhofer for his studio in Le Chef-d'oeuvre inconnu, a fact that Picasso had from Jean-Louis Barrault [Brassaï 58].)

Brassaï tells of being at Picasso's studio on 12 May 1945, Liberation Day, and having Picasso show him two recently acquired books, a Mallarmé and a Poe:

Et Picasso m'entraîne dans son petit appartement. Le "quelque chose» qu'il voulait me montrer est une première édition d'un livre de poésie de Stéphane Mallarmé. Il vient de l'acquérir. A peine l'a-t-il acheté qu'il l'a déjà enrichi d'un portrait fort ressemblant du poète. Il me dit en souriant: 
J'ai payé très cher ce livre et je voulais rattraper mon argent. . . .

Il m'ouvre aussi un Edgar Poe dont il a tracé également le portrait. Rendre unique les livres rares en y apposant sa griffe est devenu une habitude chez lui. ... (Brassaï 183)

What had brought Picasso to Mallarmé, or back to Mallarmé, at this time is hard to say for certain. Henri Mondor's editions and biographical writings were coming out at about this time, so there was renewed interest. ${ }^{10}$ It was also just a year after the arrest of Max Jacob by the Gestapo, his internment, illness, and death on 5 March 1944, a tragic series of events that may have thrown Picasso back on his past. Whatever the initial impetus, the effect of the contact with Mallarmé became intensely personal, involving, literally, Picasso's view of himself. Aside from the Liberation of Paris, there was another event, a private one of great significance, apparently: Picasso had just had a haircut. The reader of this essay can imagine my unwillingness to make too much of a seemingly trivial event, yet Picasso did just that, and so did Brassaï. It is doubtless a commonplace to point out that Picasso had an almost exclusively visual, albeit visually complex, sense of reality, but it is critical to keep in mind that things for him were as they appeared, and this seems to have included himself. Since at least 1907, Picasso had represented himself with that characteristic sweeping forelock, his bangs, which he referred to as "la mèche" $(P 92,197)$. As he aged, he used that shock of hair to cover his increasing baldness. There is a considerable difference between the photographs prior to 1945 and those thereafter where he had the characteristic shaved head of his later years. Whatever the reason, his sense of self underwent an important visual change. Here is the rest of the May 12 conversation as Brassaï recounts it:

Il avait pourtant une autre raison de me montrer ce livre ... Sous le portrait, de son écriture spasmodique, bouillonnante, il a tracé trois mots. ... Et en trois mots un événement historique de sa vie. . . Je les lis sur la page de garde:

PLUS DE MECHE! Paris, le 12 mai 1945.

Sa célèbre mèche noire, qui s'échappait de son chapeau de rapin et effrayait sa famille, l'aile noire de corbeau cent fois dessinée, caricaturée, sculptée même, qui, virant brusquement de l'extrême droite, tombait sur son front et venait balayer avec sa pointe l'oeil gauche pour remonter peu à peu sur la tempe, cette mèche a sans doute depuis longtemps disparu. Il n'en restait plus que quelques cheveux parsemés, symboliques, impuissants à masquer sa calvitie, mais que lui il voyait et entretenait encore avec soin comme vestiges de sa jeunesse. ... Ce n'est que ce matin qu'il eut le courage de rompre avec un passé révolu en enterrant solennellement la mèche morte dans ce livre de Mallarmé. . . .

Picasso: On ne peut pas être et avoir été. . . . Alors quand allez-vous me photographier sans ma mèche?

Et je m’aperçois qu'en effet ses cheveux sont coupés ras. . . . Fin de l'«époque mèche». ... . (Brassaï 183-84)

The language of being and not being is uncharacteristic of Picasso and striking for that reason. In any event, this self-reflection was somehow related to Mallar- 
mé and specifically to that poem dealing most directly with the transformation of the artist and the greatest of Mallarmé's auto-obituaries, the sonnet to Poe. I have not been able to locate the books that Picasso showed Brassaï, but I have found the preliminary drawing for inside the book cover, dated April 1945 (Fig. 1). This is a case of what Joyce might have called mallarginalia: the transcribed poem off-set in relation to the central drawing. While I lean heavily toward Mallarmé, it is not absolutely certain whether the portrait is of Mallarmé or of Poe; both have been suggested and both are possibilities. ${ }^{11}$ For Picasso, there was no essential difference between the two (as there had not been between Mallarmé and Jacob as poets), suggested by the transcription of Mallarmé's poem followed by Poe's counterfeited signature. (The Poe mentioned by Brassaï was certainly Mallarmé's translation of verse; Gallimard brought out an edition in 1945.) The poem, "Le Tombeau d'Edgar Poe," begins with Mallarmés most frequently quoted line, "Tel qu'en lui-même enfin l'éternité le change." The subject of this sonnet is the death of the poet, who is thereby transformed into his ideal self, eternally perceptible through his poetry and in his name printed on the tombstone-page. Picasso's drawing is in a sketchbook not meant for other eyes, and the transcription is not mentioned by Brassaï, suggesting that Picasso's interest in the poem was very personal. It may be that the "calme bloc déchu de quelque désastre obscur," the name-bearing tombstone, evoked the fallen diecube of earlier years. ${ }^{12}$ More directly, though, would be the thematic extension of the opening line of the Poe sonnet to express the transition from youthful vigor to present age. In the portrait one notices, above the poem, the phrase, "plus de meche [sic]," confirming Brassaï's memoir and strengthening the tie between Mallarmé's chef-d'oeuvre and Picasso's chef dur.

Picasso certainly knew from his own experience the extent to which the represented subject can mirror the artist, and would have sensed intuitively that, in writing about Poe, Mallarmé was writing about himself. What, then, of Picasso's portrait of Mallarmé? And what of Mallarmé's bangs? It is instructive to look at the probable source for the poet's likeness. Picasso certainly did not use any of the standard, frontal portraits of Edgar Allan Poe, which lack the elongated elegance we see here. It is more than likely that he had seen at one time or another Gauguin's 1891 portrait of Mallarmé, or someone's rendition of it, ${ }^{13}$ and was working from memory. The three-quarters pose is the same, albeit from the other side; the arch of the brow Picasso picks up in the shape of the eye; and then of course there are the bangs: In both the Gauguin and the Picasso, they lie down on one side of the forehead and rise on the other exposing the forehead. (Avoir été et être?.)

Those bangs will have an interesting career. In a drawing from later the same year, 1945, Picasso made the portraits of Mallarmé and Verlaine for Paul Eluard's copy of the 1885 autobiographical letter. The Mallarmé is a drawing of extreme economy of means, where the forelock is the defining characteristic of the upper head. Again, as in the Gauguin, the forelock falls on one side and rises on the other. ${ }^{14}$ 


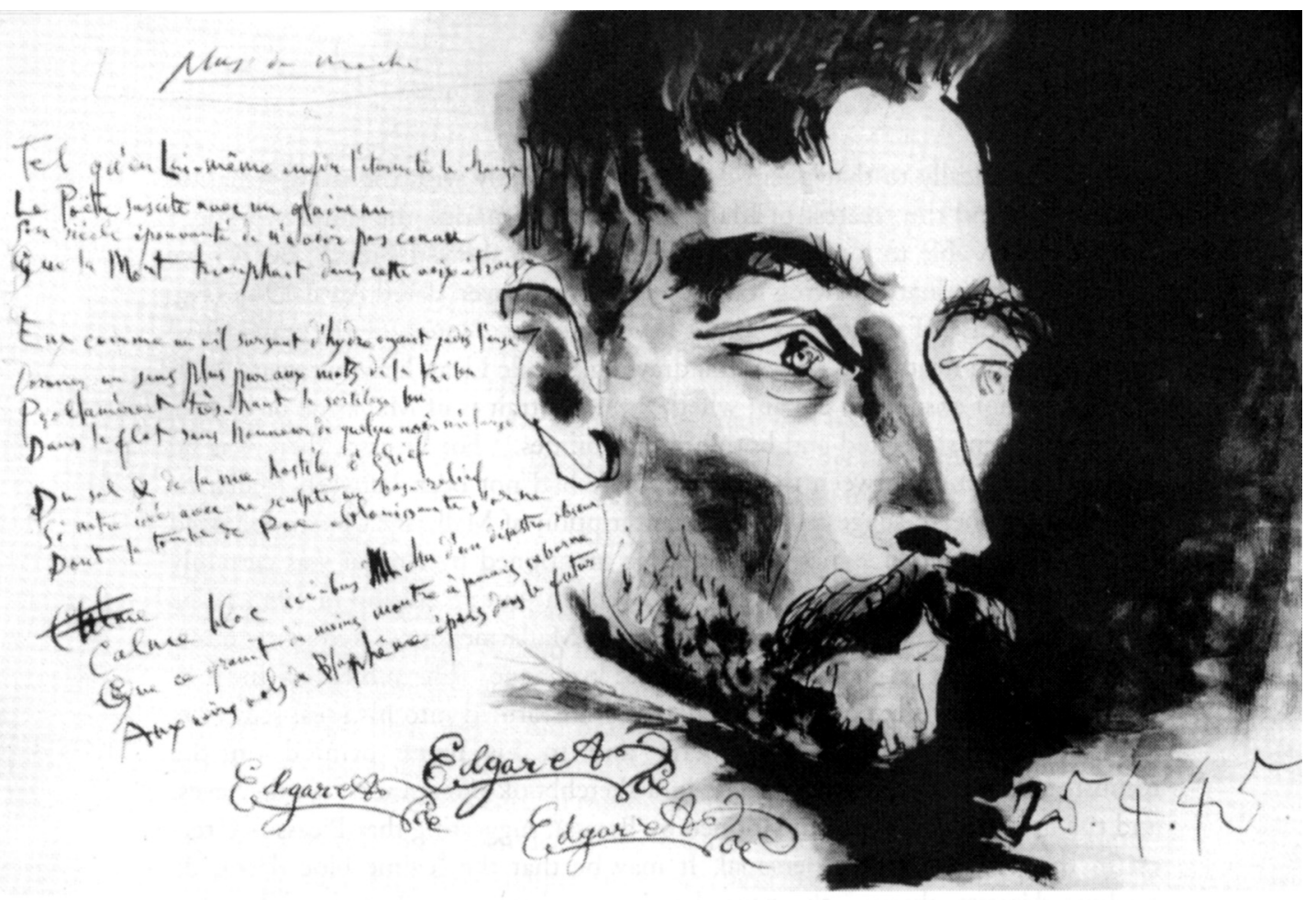

FIGURE 1. Courtesy of Réunion des Musées Nationaux

This second drawing would not be the end of the affair, however. Picasso still had one crucial step to take, which he would do in a third portrait of Mallarmé executed three years later, at the time of the fiftieth anniversary of the poet's death (Fig. 2) ${ }^{15}$ Dated 29 June 1948, it is done in red sanguine crayon. Further stylization of the features suggests that he was still working from memory, though now most definitely from Gauguin. One notices immediately the angular treatment of Mallarmé's features and senses what had been missing in the earlier Gauguin-inspired portraits: the raven, a cultural icon of Mallarmés own day referring to his translation of Poe. Gauguin's corbeau, emerging from the obscure background and looming just over Mallarmé's head, has been transferred by Picasso to the wing motif in the forelock and eyebrows. The poet's nose and chin are chiseled now into beaklike prominence. This is what one might call an indirect quotation of Gauguin by Picasso, subtler though similar to another one at play here: Gauguin's direct quotation of Manet in his portrayal of the bird, clearly taken from the frontispiece of Manet's 1875 illustrations for Mallarmé's translation of "The Raven." 16 Gauguin's visual citation suggests that his thinking about Mallarmé, like Picasso's, was especially in the visual images of painting rather than those of words. It is important, too, that the quotation from Manet should come as the expression of Gauguin's personal brand of pantheistic mysticism. For Picasso, likewise, the quotation occupies a very personal space that carries the echoes of personal experience and identity. The insistent application of the crayon on Mallarmés bangs seems to be the action of memory working itself out pictorially. 


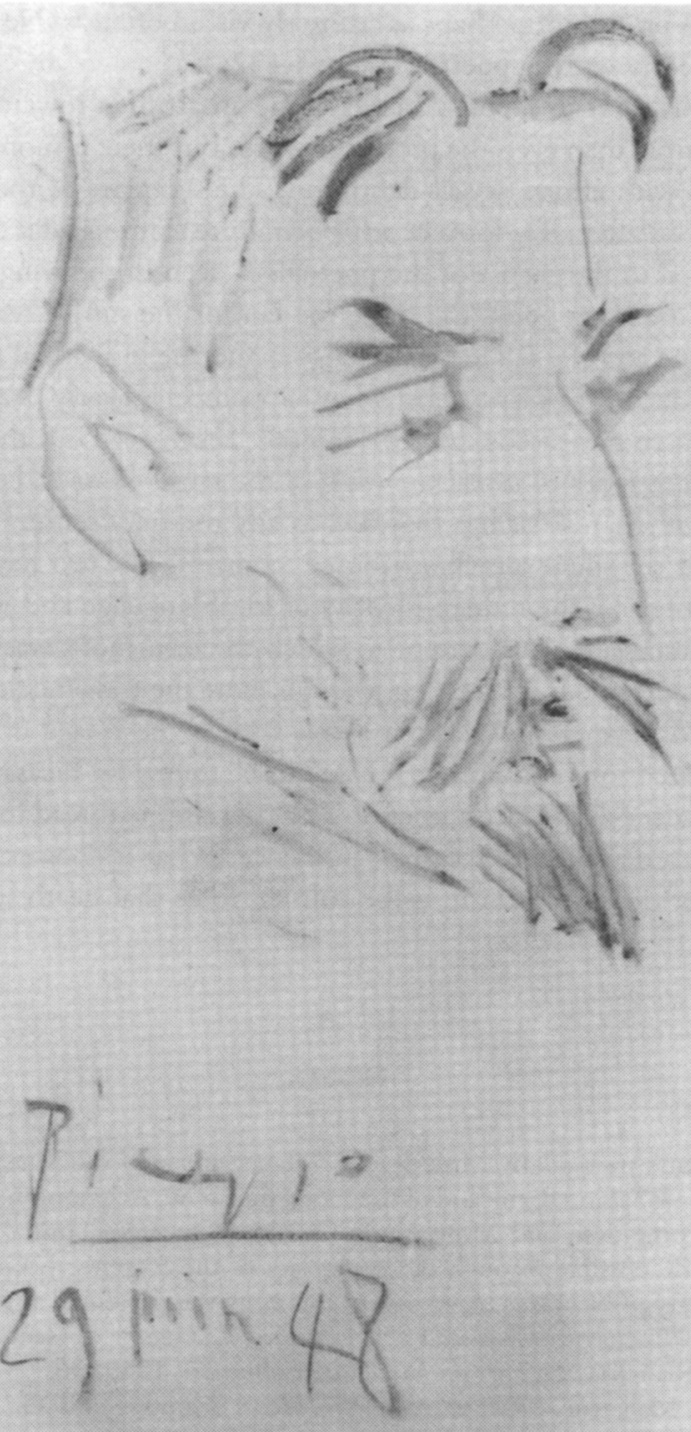

FIGURE 2. Courtesy of Collection Fondation Flandreysy-Espérandieu-Palais du Roure-Avignon

This last portrait, probably executed within the space of an hour, bears the imprint of a history of surprising complexity: the evocation of Gauguin's (and perhaps Manet's?) earlier art superimposed on a personal history where the identities of artist and subject themselves overlap, and where one can just hear behind it all the Poe sonnet and Picasso's personal reading: "On ne peut pas être et avoir été. Quand allez-vous me photographier sans ma mèche?" It is a view at once 
superficial and profound, perhaps as painterly vision often is. No wonder Degas had such difficulty writing poetry (Valéry 1.1324).

Blanchot was right to identify in Mallarmé an attitude toward language that was more essential than even the produced work. But there is more: That attitude was entangled with efforts at self-definition. The subgenre of the auto-obituary (the Tombeau) is, after all, a form of self-portraiture. Throughout Mallarmé, such reflection is tied to the theme of the poet-angel, seen in the wing image, and its metonyms of the open book, the page, the fan, or the simple feather. Attitudes toward language and the self are co-extensive, and the individual text can indeed pale beside them. In fact, this is just what happens in an early poem that is especially pertinent to our discussion. In "Sainte" (1865; OC 53), the opened score of the Magnificat fades to reveal the wing of the angel come to hear Cecilia play and sing it. But she never sings that text in any ordinary sense. "Musicienne de silence," hers is the silent speech attributed to angels. The text has vanished both to reveal and become the hidden identity of ideal language and ideal self. Picasso was surely unaware of the extent to which the bird motif was appropriate to his Mallarmé portrait. It is arresting, though, how the transmission of the poet's likeness should have communicated along with it the image of such a fundamental preoccupation, and how that came to be folded by Picasso into a similar one. The Mallarmé-Picasso conjunction lacks the simple thread for it to carry the weight of, say, a demonstrable case of influence. What it does express, one hundred years after the poet's death, is the cultural force that death still carries.

\section{University of Nebraska}

\section{NOTES}

I wish to thank particularly Mme Jeanne-Yvette Sudour of the Musée Picasso for her patient help, Mme Sabine Barnicaud of the Hôtel du Roure, Avignon, the archival services of the Musée Pompidou, and Mme Agnès Gauthier-Chartrette. Initial research on this project was made possible through the generosity of the Florence J. Gould Foundation and the University of Nebraska. A version of this essay was presented at the October 1997 Colloquium in Nineteenth-Century French Studies, University of Georgia.

1. Maurice Blanchor, La Part du feu (Paris: Gallimard, 1949) 36.

2. Stéphane Mallarmé, Oeuvres complètes, Henri Mondor and G. Jean-Aubry, eds. (Paris: Gallimard, Bibliothèque de la Pléiade, 1945) 54.

3. An example is Robert Motherwell's collage, "Mallarmé's Swan." It is an abstract work in ochers, pinks, and blues, having nothing to do with the black and white sonnet. The fact that the title may not have been Motherwell's first choice is less important than that the title should have been chosen at all.

4. Brassaï, Conversations avec Picasso (Paris: Gallimard, 1964) 157, 183.

5. Max Jacob et Picasso, Hélène Seckel, ed. (Paris: Réunion des Musées Nationaux, 1994) 116.

6. Paul Valéry, Oeuvres Complètes, 2 vols., Jean Hytier, ed. (Paris: Gallimard, Bibliothèque de la Pléiade, 1957) 1.622.

7. Sydney Lévy, The Play of the Text: Max Jacob's Le Cornet à dés (Madison: U of Wisconsin P, 1981) 129. 
8. Pablo Picasso: a Retrospective, William Rubin, ed. (New York: The Museum of Modern Art, 1980) 175.

9. In Finnegans Wake, James Joyce makes the same pun, though in English: un coup de dés becomes cup on tay. See: David Hayman, Joyce et Mallarmé, 2 vols. (Paris: Lettres Modernes, 1956) 2.144. For Picasso's collages, Mallarmé and games of chance, see Reinhard Kruger, "Picasso liest Mallarmés Un coup de dés," Lendemains $(10,1985)$ 38-46.

10. In 1945, Gallimard brought out editions of the Poesies complètes and of the Poe translations.

11. Ink, Musée Picasso, Carnet X. It is listed as a portrait of Poe, but Jeanne-Yvette Sudour, the museum's principal documentaliste, and I concluded in 1991 that the subject is more likely Mallarmé, based on the probable source of the Gauguin portrait. Figure 1 is reproduced with kind permission from the Réunion des Musées Nationaux.

12. Hayman has seen this in Joyce, but not of course in the context of cubism (46).

13. The Musée Pompidou has in its archives a drawing of Mallarmé by Raoul Dufy, dated 1943, that appears to be a composite of both the Gauguin and Manet portraits. These latter are widely reproduced.

14. Permission for this drawing could unfortunately not be obtained prior to going to press with this article.

15. Sanguine on paper. Fondation Flandreysy-Espérandieu, Avignon. Figure 2 is reproduced with kind permission.

16. The complete Illustrations from Delacroix's Faust and Manet's The Raven (Mallarmé translation), Breon Mitchel, ed. (New York: Dover Publications, 1981). 